\title{
PENGARUH PENERAPAN LABORATORIUM VIRTUAL PHET TERHADAP MOTIVASI BELAJAR IPA SISWA PADA MATERI GERAK LURUS
}

\author{
Rahmiati Darwis'), Muhammad Rizal Hardiansyah¹) \\ 1)Program Studi Tadris IImu Pengetahuan Alam, Fakultas IImu Tarbiyah dan Keguruan, Institut Agama Islam \\ Negeri Ambon, Kota Ambon, Provinsi Maluku, Indonesia) \\ Corresponding author : Rahmiati Darwis \\ E-mail : rahmiati.darwis@iainambon.ac.id
}

Diterima 30 Oktober 2021, Disetujui 05 November 2021

\begin{abstract}
ABSTRAK
Penelitian ini bertujuan untuk mengetahui bagaimana pengaruh penerapan laboratorium virtual $\mathrm{PhET}$ terhadap motivasi belajar IPA siswa pada materi gerak lurus. Penelitian ini dikategorikan sebagai penelitian eksperimen dengan jenis quasi eksperimen yang menggunakan desain posttest only control group. Populasi dalam penelitian ini adalah seluruh siswa kelas VIII MTs Negeri Ambon tahun ajaran 2020/2021 dengan sampel yaitu kelas $\mathrm{VIII}_{4}$ sebagai kelas eksperimen dan kelas $\mathrm{VIII}_{5}$ sebagai kelas kontrol yang ditentukan dengan teknik sampling yaitu simple random sampling. Instrument yang digunakan dalam penelitian ini adalah kuesioner motivasi belajar IPA siswa yang berisi 46 butir pernyataan (22 butir pernyataan positif dan 24 butir pernyataan negatif). Data hasil pengisian angket motivasi dianalisis dengan uji hipotesis t-test one way menggunakan spss 26 . Hasil pengujian hipotesis diperoleh nilai signifikansi sebesar 0,000 $<0,05$ yang berarti $\mathrm{H}_{0}$ ditolak dan $\mathrm{H}_{1}$ diterima. Ini menunjukkan bahwa terdapat perbedaan pengaruh yang signifikan motivasi belajar siswa antara siswa yang belajar IPA menggunakan praktikum laboratorium virtual PhET dengan siswa yang belajar IPA secara konvensional. Sehingga dapat disimpulkan bahwa penerapan laboratorium virtual PhET memberikan pengaruh motivasi belajar IPA siswa yang lebih baik pada materi gerak lurus.
\end{abstract}

Kata kunci: Laboratorium virtual; Simulasi PhET; Motivasi belajar; Gerak lurus

\begin{abstract}
This research aimed to know the effect of using virtual laboratory PhET towards students' motivation in learning science on linear motion. This research is quasy experimental research that uses posttest only control group design. The population of this research is all grade VIII students of MTs Negeri 1 Ambon in the academic year 2020/2021 and the sample of this research is grade $\mathrm{VIII}_{4}$ as experimental group and $\mathrm{VIII}_{5}$ as control group that determined by simple random sampling technique. The instrument that used to collect the data is questionnaire of students' motivation in learning science which have 46 items (22 positive questions and 24 negative questions). The data The data were processed in the percentage and analysed by statistical formula of t-test by SPSS 26 . The result of t-test shows that Sign. $0000<$ 0,05 , it mens that there is a significant difference effect of students' motivation in learning science on the linear motion. Therefore, it can be concluded that implementation of virtual laboratorial PhET has positive effect towards students' motivation in learning science on the linear motion.
\end{abstract}

Keywords: virtual laboratory; PhET simulation; Motivation in learning; Linear motion

\section{PENDAHULUAN}

Pembelajaran Ilmu Pengetahuan Alam (IPA) tidak dapat dipisahkan dari kegiatan praktikum. Kegiatan praktikum IPA merupakan kegiatan belajar yang berkaitan dengan adanya serangkaian kegiatan eksperimen yang dilakukan siswa dengan tujuan untuk membuktikan maupun menemukan suatu konsep IPA. Praktikum laboratorium IPA memberikan kesempatan kepada siswa untuk melakukan suatu percobaan dan menganalisis data yang diperoleh sesuai dengan tujuan percobaan yang dilakukan. Dengan adanya kegiatan praktikum, siswa dapat memperoleh gambaran secara langsung fenomenafenomena alam yang terjadi melalui penyelidikan. Praktikum IPA sangat penting untuk dilakukan karena merupakan penunjang dalam kegiatan pembelajaran IPA untuk menemukan maupun menjelaskan prinsipprinsip tertentu.

Pada awal tahun 2020, kegiatan praktikum laboratorium IPA di sekolah-sekolah tidak berjalan sesuai dengan yang diharapkan. Pemerintah menerapkan program belajar dari rumah masing-masing selama masa pandemi 
Covid-19. Guru dan siswa tidak lagi bertemu secara langsung dalam melaksanakan pembelajaran khususnya kegiatan praktikum di laboratorium yang ada di sekolah. Kurikulum IPA di SMP/MTs memiliki beberapa kompetensi dasar yang menekankan pada aktivitas laboratorium. Sehingga, kemampuan siswa dalam pembelajaran IPA akan menyeluruh jika teori dan praktik dapat berjalan.

Berdasarkan hasil observasi pada salah satu sekolah menengah pertama di Kota Ambon ditemukan bahwa sejak pandemi covid19 kegiatan praktikum laboratorium tidak lagi dilaksanakan. Hal ini sebabkan karena guru dan siswa tidak dapat bertemu lagi di dalam kelas sebab pembelajaran yang dilaksanakan secara daring. Pembelajaran IPA dilakukan secara daring dengan metode ceramah, pembelajaran ini dilakukan kurang interaktif sehingga siswa cepat bosan karena pembelajaran dilakukan hanya teori saja tanpa praktek. Selain itu, guru juga kadang memberikan bahan presentasi untuk dibaca siswa secara mandiri, sehingga, sebagian besar siswa masih belum mampu mengaitkan konsep IPA yang telah dipelajari dengan permasalahan yang diberikan, serta kesulitan dalam menentukan persamaan matematis yang digunakan. Berdasarkan hasil wawancara di sekolah, siswa mengungkapkan bahwa mereka mengalami kesulitan dalam memahami pembelajaran yang diberikan dan pembelajaran secara daring membuat mereka cepat bosan dan malas belajar. Oleh karena itu, perlu adanya alternatif pembelajaran yang dapat meningkatkan motivasi belajar siswa dimasa pandemi Covid-19.

Laboratorium virtual dalam pembelajaran IPA merupakan suatu media sebagai tempat terlaksananya kegiatan praktikum secara elektronik melalui penggunaan simulasi yang ada di komputer. Laboratorium ini dapat menjadi laboratorium alternatif dalam pelaksanaan praktikum di laboratorium nyata karena laboratorium ini merupakan salah satu laboratorium alternatif yang memiliki peran memudahkan siswa untuk mendalami suatu konsep sains, membangkitkan minat belajar siswa serta dapat dijadikan solusi dari keterbatasan alat dan bahan di laboratorium. Dengan kata lain, laboratorium virtual adalah serangkaian kegiatan praktikum yang memiliki alat dan bahan praktikum online yang dijalankan menggunakan laptop dapat mensimulasikan kegiatan praktikum di laboratorium seperti seseorang sedang berada pada laboratorium yang sesungguhnya (Nainggolan, 2017).

PhET (Physics and Education

Technology) merupakan salah satu jenis laboratorium virtual yang dikembangkan dengan tujuan sebagai media bagi siswa dalam melaksanakan kegiatan praktikum baik yang dapat diamati secara makrokopik maupun submikroskopik dalam pembelajaran IPA. Tujuan pembuatan software simulasi interaktif PhET ini adalah "help students visually comprehend concepts, ensure educational effectiveness and usability" yaitu membantu siswa untuk memvisualisasikan konsep secara utuh dan jelas dan menjamin pendidikan yang efektif serta kebergunaan yang berkelanjutan (Wieman, 2002).

Laboratorium virtual PhET merupakan media komputasi yang berisi animasi pembelajaran IPA yang disajikan dalam website. Dalam PhET terdapat subfile yang dapat dioperasikan secara mandiri dan animasi seperti apa yang ingin diperlihatkan. Aplikasi ini menampilkan konsep matematika dan IPA yang bersifat abstrak dan materi tertentu dapat dengan mudah dipaparkan melalui aplikasi ini, sehingga siswa akan lebih mudah memahami konsep yang dipelajari (Purwanto dan Hendri, 2016). Simulasi PhET berisi gambar bergerak yang dibuat layaknya benda aslinya sehingga siswa dapat secara mandiri bereksplorasi. Salah satu kelebihan $\mathrm{PhET}$ ini yaitu simulasi ini sangat menarik dan asyik, sehingga mampu menarik motivasi belajar IPA siswa karena menyajikan fenomena melalui model-model konseptual fisis yang lebih mudah dipahami oleh siswa (Wuryaningsih, 2014).

Pada masa pandemi Covid-19, siswa mengalami penurunan motivasi untuk belajar, salah satu penyebabnya adalah terlalu banyak tugas daring yang menyebabkan siswa tidak lagi fokus dalam memahami setiap materi yang diberikan, melainkan siswa sibuk untuk menyelesaikan serentetan tugas yang diberikan agar dapat dikumpulkan tepat waktu. Oleh karena itu, seorang guru perlu adanya suatu inovasi dalam pembelajaran, agar pembelajaran daring yang dilaksanakan tidak membosankan.

Adanya aktivitas dalam laboratorium virtual PhET merangsang minat belajar siswa karena laboratorium virtual ini berisi simulasi yang interaktif, dimana siswa dapat mengoperasikan aplikasinya secara mandiri dan mudah digunakan. Konsep-konsep yang abstrak yang tidak dapat diamati secara langsung dapat tergambarkan melalui laboratorium virtual ini, sehingga pembelajaran melalui laboratorium ini lebih menarik dan mampu menumbuhkan motivasi belajar siswa.

Pembelajaran IPA mengaitkan konsep sains dengan fenomena yang terjadi dalam kehidupan sehari-hari. Salah satu materi IPA 
yang sangatlah dekat dengan kehidupan sehari-hari siswa adalah materi gerak lurus. Materi gerak lurus merupakan salah satu materi dalam pembelajaran IPA yang memiliki banyak konsep abstrak. Sehingga, untuk mengamati secara langsung dan membuktikan teori dari materi tersebut dapat dilaksanakan melalui praktikum laboratorium virtual PhET.

Bertolak dari pandangan di atas, peneliti tertarik untuk melakukan penelitian mengenai proses pembelajaran IPA yang menerapkan laboratorium virtual PhET terhadap motivasi belajar siswa kelas VIII pada materi gerak lurus. Oleh karena itu, penelitian ini bertujuan untuk mengetahui bagaimana pengaruh laboratorium virtual PhET terhadap motivasi belajar siswa pada materi gerak lurus.

\section{METODE PENELITIAN \\ Jenis dan Desain Penelitian}

Sesuai dengan tujuan penelitian, penelitian ini dikategorikan sebagai penelitian eksperimen dengan jenis quasi eksperimen (eksperimen semu). Penelitian ini menggunakan dua kelas yaitu kelas eksperimen (kelas yang diberi perlakuan berupa pembelajaran laboratorium virtual PhET) dan kelas kontrol (kelas dengan pembelajaran konvensional). Kedua kelas diberi perlakuan yang berbeda. Desain penelitian ini adalah posttest only control group design (Fraenkel \& Wallen, 2007).

Tabel 1. Desain posttest only control group

\begin{tabular}{ccc}
\multicolumn{3}{c}{ design } \\
\hline $\mathrm{R}$ & $\mathrm{X}$ & $\mathrm{O}_{1}$ \\
\hline $\mathrm{R}$ & - & $\mathrm{O}_{2}$
\end{tabular}

$$
\begin{array}{ll}
\hline \text { Keterangan: } \\
\mathrm{R} & =\text { Random } \\
\mathrm{O}_{1} & =\text { Posttest Kelas Eksperimen } \\
\mathrm{O}_{2} & =\text { Posttest Kelas Kontrol } \\
\mathrm{X} & =\text { Perlakuan (penerapan laboratorium } \\
& \text { virtual PhET) }
\end{array}
$$

\section{Lokasi Penelitian}

Penelitian ini dilakukan di MTs Negeri Kota Ambon. Sebelum pelaksanaan penelitian, peneliti terlebih dahulu meminta izin kepada kepala sekolah MTs Negeri Kota Ambon dan bertemu dengan guru-guru IPA di sekolah tersebut. Peneliti kemudian menyampaikan prosedur rencana penelitian di sekolah tersebut kepada guru bidang studi IPA kelas VIII. Pelaksanaan penelitian dilaksanakan secara daring, baik itu pelaksanaan ujian, pengisian angket maupun kegiatan pembelajaran laboratorium virtual dilaksanakan secara daring dirumah siswa masing-masing.

\section{Subjek Penelitian}

Subjek dalam penelitian ini melibatkan populasi yaitu seluruh siswa kelas VIII tahun ajaran 2021/2022 pada sekolah MTs Negeri Ambon sebanyak 11 kelas (416 siswa).

Mengingat banyaknya atau luasnya populasi tersebut dan juga terbatasnya kemampuan yang ada pada peneliti, baik dari degi materi maupun kesempatan yang ada sehingga kurang memungkinkan untuk meneliti secara luas atau menyeluruh. Oleh karena itu, agar bisa terjangkau penelitian dan tanpa mengurangi arti populasi, maka peneliti menyelidiki sebagian dari populasi yang ada tetapi mewakili seluruh populasi yang disebut dengan sampel.

Penentuan sampel dalam penelitian ini dipilih dengan teknik simple random sampling karena populasi bersifat homogen. Populasi bersifat homogen terlihat dari tidak adanya label kelas favorit ataupun kelas unggulan untuk tiap tingkatan di sekolah tersebut, pembagian siswa dilakukan secara acak tanpa memperhatikan strata yang ada dalam populasi. Dari penentuan sampel diperoleh dua kelas, kelas VIII-4 sebagai kelas eksperimen dan kelas VIII-5 sebagai kelas kontrol, masing-masing kelas berjumlah 38 siswa.

\section{Teknik Pengumpulan Data}

Teknik pengumpulan data digunakan dalam rangka mengambil atau mengumpulkan informasi sesuai dengan yang dibutuhkan. Dalam penelitian ini, teknik pengumpulan datanya meliputi kuesioner motivasi belajar IPA siswa.

Kuesioner merupakan teknik pengumpulan data yang dilakukan dengan cara memberikan penyataan tertulis atau berupa pertanyaan kepada responden. Responden dalam penelitian ini adalah siswa kelas VIII MTsN Ambon. Kuesioner berupa angket motivasi belajar IPA siswa. Kuesioner ini berisi 46 butir pernyataan (22 butir pernyataan positif dan 24 butir pernyataan negatif) terkait bagaimana motivasi belajar siswa setelah penerapan laboratorium virtual dalam pembelajaran IPA di kelas secara daring.

Indikator motivasi belajar IPA dalam penelitian ini terdiri dari aspek dorongan internal dan eksternal. Indikator aspek dorongan internal meliputi: (1) adanya hasrat dan keinginan berhasil, (2) adanya dorongan dan kebutuhan dalam belajar, (3) adanya harapan dan cita-cita masa depan, sedangkan indikator untuk aspek dorongan eksternal meliputi: (1) adanya penghargaan dalam belajar, (2) adanya kegiatan yang menarik dalam belajar, dan (3) adanya lingkungan belajar yang kondusif 
sehingga memungkinkan siswa dapat belajar dengan baik.

Kuesioner ini menggunakan skala Likert karena terkait respon/pendapat siswa. Peneliti menggunakan skala likert yang berisi 5 tingkat preferensi jawaban dengan pilihan yaitu:

$$
\begin{array}{ll}
\mathrm{SS} & =\text { Sangat Setuju } \\
\mathrm{S} & =\text { Setuju } \\
\mathrm{KS} & =\text { Kurang Setuju } \\
\mathrm{TS} & =\text { Tidak Setuju } \\
\mathrm{STS} & =\text { Sangat Tidak Setuju }
\end{array}
$$

\section{Teknik Analisis Data}

Data hasil pengisian angket motivasi belajar IPA siswa dianalisis dengan tahapan sebagai berikut.

1) Melakukan penskoran motivasi belajar, lalu dilanjutkan dengan mengkonversinya ke dalam nilai motivasi (Arikunto, 2013);

Nilai Motivasi $=\frac{\text { Skor yang Diperoleh }}{\text { Skor Maksimum }} \times 100$

2) Mengelompokkan nilai motivasi ke dalam tiga kategori motivasi belajar yaitu tinggi, sedang dan rendah. Adapun pedoman pengkategorian motivasi belajar disajikan ke dalam Tabel 2 (Arikunto, 2013).

Tabel 2. Pengkategorian Motivasi belajar

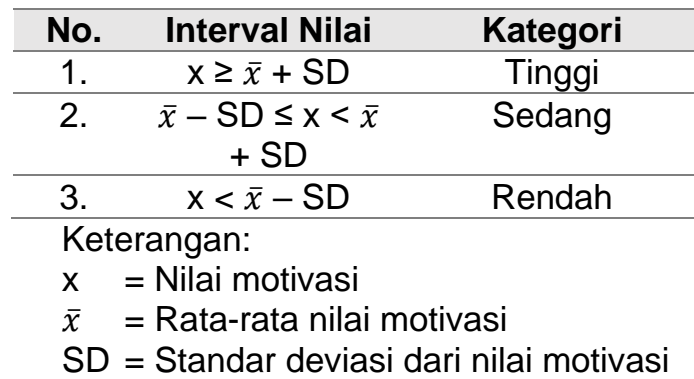

3) Menentukan nilai persentase motivasi belajar dengan menggunakan rumus:

$\%$ tiap indikator $=\frac{\text { jumlah skor }}{\text { skor total }} \times 100 \%$

Nilai persentase tiap indikator yang didapat kemudian ditafsirkan kedalam kriteria sebagai berikut.

Tabel 3. Kriteria Angket Motivasi Belajar tiap Indikator (Arikunto, 2013);

\begin{tabular}{cc}
\hline Persentase & Kriteria \\
\hline $76 \%-100 \%$ & Baik \\
\hline $56 \%-75 \%$ & Cukup \\
\hline $41 \%-55 \%$ & Kurang baik \\
\hline $0 \%-40 \%$ & Tidak baik \\
\hline
\end{tabular}

4) Tahap berikutnya adalah melakukan uji hipotesis yaitu t-test one way juga menggunakan SPSS Statistics 26 dengan tingkat signifikansi pada uji ini 5\%. Adapun keputusan uji ini yaitu dengan kriteria apabila Sig. < 0,05 maka $\mathrm{HO}$ ditolak dan $\mathrm{H1}$ diterima. Sebelum dilakukan uji ini, maka dilakukan uji prasyarat terlebih dahulu yaitu uji normalitas dan uji homogenitas.

\section{HASIL DAN PEMBAHASAN Hasil Penelitian}

Hasil analisis perhitungan skor untuk motivasi belajar IPA siswa kelas VIII MTs Negeri Ambon tahun ajaran 2021/2022 selengkapnya dapat dilihat pada Gambar 1 .

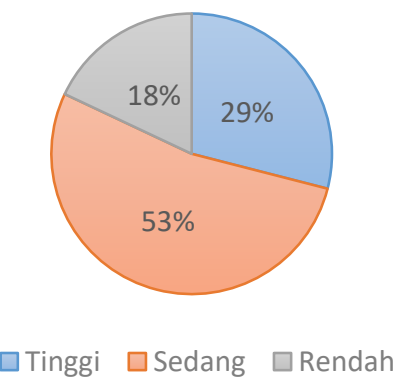

Gambar 1. Persentase Tingkat Motivasi Belajar Siswa Kelas Eksperimen

Adapun perbandingan motivasi belajar IPA kelas eksperimen dan kelas kontrol dapat terlihat pada Gambar 2.

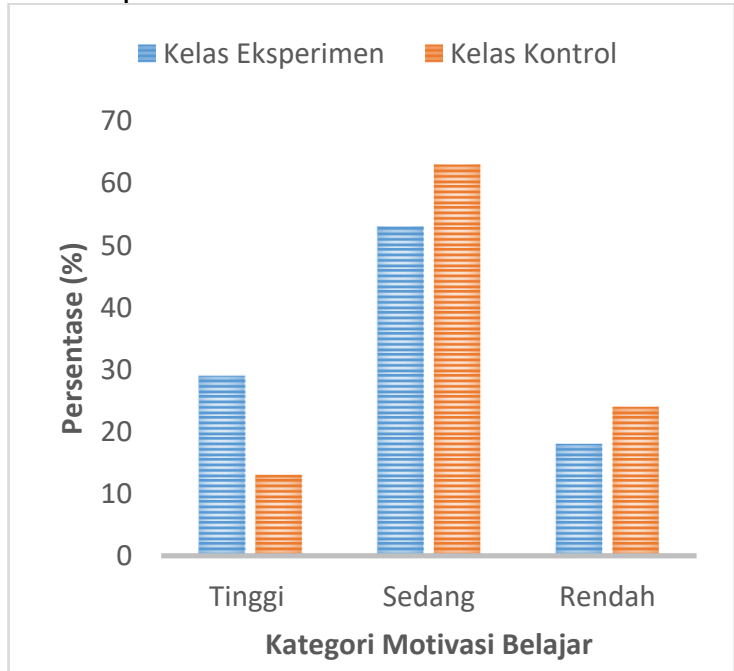

Gambar 2. Perbandingan Kategori Motivasi

Belajar Siswa Kelas Eksperimen dan Kontrol

Berdasarkan diagram di atas, terlihat bahwa kedua kelas sampel, memiliki persentase motivasi belajar IPA paling besar berada pada kategori sedang. Siswa pada kelas eksperimen memiliki persentase motivasi belajar dengan kategori tinggi lebih besar dibandingkan kelas kontrol sedangkan siswa pada kelas kontrol memiliki persentase motivasi belajar dengan kategori rendah lebih besar dibandingkan kelas eksperimen.

Persentase dan kategori motivasi belajar IPA tiap indikator siswa yang telah diajar menggunakan laboratorium virtual PhET disajikan dalam Tabel 4. 
Tabel 4. Persentase Motivasi Belajar IPA tiap Indikator

\begin{tabular}{clll}
\hline No. & Indikator Motivasi & $\%$ & Kriteria \\
\hline 1. & $\begin{array}{l}\text { Adanya hasrat dan } \\
\text { keinginan berhasil }\end{array}$ & $79 \%$ & Baik \\
\hline 2. & $\begin{array}{l}\text { Adanya dorongan } \\
\text { dan kebutuhan } \\
\text { dalam belajar }\end{array}$ & $92 \%$ & Baik \\
\hline 3. & $\begin{array}{l}\text { Adanya harapan } \\
\text { dan cita - cita } \\
\text { masa depan }\end{array}$ & $80 \%$ & Baik \\
\hline 4. & $\begin{array}{l}\text { Adanya } \\
\text { penghargaan } \\
\text { dalam belajar }\end{array}$ & $73 \%$ & Cukup \\
\hline 5. & $\begin{array}{l}\text { Adanya kegiatan } \\
\text { yang menarik } \\
\text { dalam belajar }\end{array}$ & $85 \%$ & Baik \\
\hline 6. & $\begin{array}{l}\text { Adanya lingkungan } \\
\text { belajar yang } \\
\text { kondusif sehingga } \\
\text { memungkinkan } \\
\text { peserta didik dapat } \\
\text { belajar dengan } \\
\text { baik. }\end{array}$ & & \\
\hline Rata-rata & $87 \%$ & Baik \\
\hline
\end{tabular}

Berdasarkan Tabel 4 terlihat bahwa ada lima indikator motivasi belajar IPA berada pada kriteria baik dan hanya satu indikator motivasi belajar IPA yang berada pada kriteria cukup. Secara keseluruhan, motivasi belajar IPA siswa dalam pembelajaran laboratorium virtual PhET pada materi pokok gerak lurus berada pada kriteria baik.

\section{Pembahasan}

Motivasi belajar siswa diukur menggunakan angket/kuesioner motivasi belajar IPA. Instrument ini diperlukan untuk mengetahui bagaimana motivasi belajar IPA siswa setelah pembelajaran dilaksanakan. Angket ini diberikan kepada kelas eksperimen dan kelas kontrol dengan tujuan untuk melihat perbedaan motivasi belajar kedua kelas tersebut. Sampel untuk angket motivasi belajar IPA adalah siswa kelas eksperimen dan kelas kontrol masing-masing berjumlah 38 siswa. Angket ini diberikan setelah pembelajaran dan ujian posttest telah dijalankan dan diisi secara online oleh siswa.

Hasil angket menunjukkan bahwa siswa yang belajar IPA dengan adanya praktikum laboratorium virtual PhET memiliki motivasi belajar yang baik. Siswa memiliki motivasi belajar dengan kategori tinggi sebesar $29 \%$ dan kategori sedang 53\%, sedangkan hanya $18 \%$ siswa yang memiliki motivasi belajar dengan kategori rendah. Hal ini menunjukkan bahwa dengan adanya laboratorium virtual PhET dalam pembelajaran
IPA, siswa lebih termotivasi dalam pembelajaran.

Pembelajaran IPA dengan praktikum melalui laboratorium virtual PhET menyajikan media interaktif berupa gambar-gambar atau animasi yang bergerak dibuat seperti game. Siswa mendapatkan pengalaman belajar dengan melakukan aktivitas bereksplorasi melalui simulasi-simulasi dalam PhET yang menekankan korespondensi antara peristiwa sains dalam kehidupan sehari-hari atau fenomena-fenomena yang nyata disajikan secara konseptual, lebih efisien, dan lebih mudah untuk dipahami, sehingga pembelajaran ini menciptakan suasana belajar yang menarik yang mampu meningkatkan motivasi belajar siswa. Hal ini sejalan dengan penelitian yang dilakukan oleh Perkins, et al (2006). yang memperoleh hasil bahwa laboratorium virtual PhET mampu memberikan kesan yang menarik, positif, dan menghibur serta mampu memberikan penjelasan secara mendalam tentang suatu fenomena alam yang terjadi. Oleh karena itu, siswa yang belajar menggunakan simulasi PhET merasa senang dan mudah untuk mempelajarinya. Selanjutnya Faizi (2013) mengemukakan bahwa penggunaan media dalam kegiatan pembelajaran mampu menarik motivasi belajar siswa sehingga perhatian siswa terhadap materi pembelajaran menjadi meningkat.

Pembelajaran IPA dengan praktikum melalui laboratorium virtual PhET dimasa Pandemi Covid-19 menjadi pilihan yang efektif bagi guru. Pembelajaran ini dirancang dengan baik dan menyenangkan, mampu menciptakan suasana nyaman, santai sehingga siswa focus mengikuti pembelajaran. Kegiatan praktikum virtual PhET dilaksanakan dan diakses oleh semua siswa di rumah. Waktu yang diberikan sangat fleksibel namun tetap harus sesuai dengan ketentuan yang dirancang oleh guru. Pembelajaran ini dirancang dengan suasana menyenangkan, demi untuk melatih cara berpikir dan beraktivitas siswa layaknya seorang ilmuan. Guru memberikan ruang ekspresi dan ruang eksplorasi dalam melakukan percobaan sains sehingga siswa menjadi lebih termotivasi dan mampu mengasah penalarannya.

Berdasarkan hasil pengujian hipotesis variabel motivasi belajar siswa, diperoleh nilai signifikansi sebesar 0,000 0,05 yang berarti $\mathrm{H}_{0}$ ditolak dan $\mathrm{H}_{1}$ diterima. Hal ini berarti terdapat perbedaan yang signifikan dari kedua kelas. Siswa yang belajar IPA dengan kegiatan praktikum laboratorium virtual PhET memiliki perbedaan yang signifikan dengan siswa yang belajar IPA tanpa adanya kegiatan praktikum laboratorium virtual PhET. Persentasi motivasi 
belajar siswa melalui pembelajaran konvensional dengan kategori tinggi hanya sebesar $13 \%$, kategori sedang sebesar $63 \%$, dan kategori rendah sebesar $24 \%$. Hal ini menunjukkan motivasi belajar yang lebih baik pada siswa yang belajar IPA dengan kegiatan praktikum laboratorium virtual PhET. Hal ini menunjukkan penting adanya kegiatan praktikum dalam pembelajaran IPA, karena dengan adanya kegiatan praktikum mampu membangkitkan motivasi belajar siswa dan menjadi penunjang dalam pembelajaran IPA. Hal ini sejalan dengan penelitian yang dilakukan oleh Meilinda (2012) yang menunjukkan bahwa penerapan kegiatan praktikum pada mata pelajaran IPA dapat membuat siswa menjadi lebih tertarik dan termotivasi dalam proses pembelajaran, serta siswa dapat dengan mudah memahami konsep-konsep IPA. Marlinda, dkk (2016) memperoleh hasil penelitian yaitu peningkatan motivasi dan aktivitas belajar peserta didik pada pembelajaran dengan laboratorium simulasi $P h E T$ lebih baik dibandingkan dengan metode eksperimen.

Terdapat enam indikator motivasi belajar yang diukur dalam penelitian ini, yaitu: 1) adanya hasrat dan keinginan berhasil, 2) adanya dorongan dan kebutuhan dalam belajar, 3) adanya harapan dan cita-cita masa depan, 4) adanya penghargaan dalam belajar, 5) adanya kegiatan yang menarik dalam belajar, dan 6) adanya lingkungan belajar yang kondusif sehingga memungkinkan siswa dapat belajar dengan baik. Berdasarkan perhitungan persentasi, lima dari enam indikator motivasi belajar tersebut telah diperoleh hasil dengan kriteria baik dan hanya satu indikator yang memiliki kriteria motivasi belajar yang cukup yaitu adanya penghargaan dalam belajar. Indikator adanya penghargaan dalam belajar merupakan salah satu aspek dorongan eksternal motivasi belajar. Indikator penghargaan dalam belajar IPA siswa akan lebih baik jika diberikan penghargaan atau diberikan hadiah, pujian dan lain-lain.

Dengan termotivasinya siswa dalam pembelajaran laboratorium virtual $\mathrm{PhET}$ pada mata pelajaran IPA bila dilaksanakan secara berkelanjutan, pembelajaran ini mampu menumbuhkan kemauan dan kerja keras dalam diri siswa sehingga jika dapat tersalurkan dengan baik, dapat memberikan prestasi belajar yang lebih baik. Motivasi merupakan faktor penentu dan berfungsi sebagai dasar, menimbulkan, dan mengarahkan perbuatan. Motivasi belajar dapat menentukan baik tidaknya dalam mencapai tujuan, sehingga semakin besar motivasinya akan semakin besar kesuksesan, tampak gigih, tidak mau menyerah, dan giat belajar untuk meningkatkan prestasinya.

\section{SIMPULAN DAN SARAN Simpulan}

Berdasarkan hasil penelitian dan pembahasan sebelumnya, diperoleh simpulan yaitu: (1) penerapan laboratorium virtual PhET berpengaruh secara signifikan dalam membangkitkan motivasi belajar IPA pada materi gerak lurus. (2) Indikator motivasi belajar IPA siswa yang diajar menggunakan laboratorium virtual $\mathrm{PhEt}$ yang memiliki persentase paling tinggi adalah adanya dorongan dan kebutuhan dalam belajar sedangkan indikator motivasi belajar IPA siswa yang memiliki persentase paling rendah adalah adanya penghargaan dalam belajar. Motivasi belajar siswa dalam pembelajaran laboratorium virtual PhET memiliki kriteria baik karena menurut siswa, pembelajaran tersebut menyenangkan dan mampu menghilangkan kejenuhan mereka dalam belajar IPA.

\section{Saran}

Berdasarkan penelitian yang telah dilakukan, maka peneliti memberikan saran, yaitu:

1. Penerapan laboratorium virtual PhET dapat digunakan dalam pembelajaran IPA materi gerak lurus dengan hasil yang memuaskan. Penerapan laboratorium virtual PhET ini juga dapat digunakan sebagai alternatif pada materi IPA yang lain. Akan tetapi, siswa tetap perlu diajak untuk melakukan praktikum di laboratorium sesungguhnya.

2. Guru perlu memberikan apresiasi atau penghargaan terhadap prestasi belajar siswa agar siswa memiiki motivasi belajar yang lebih baik dalam belajar IPA melalui laboratorium virtual $\mathrm{PhET}$.

3. Siswa perlu diberi pembiasaan dalam praktek menggunakan laboratorium virtual $\mathrm{PhET}$ agar waktu yang digunakan dalam melaksanakan kegiatan praktikum virtual tidak terlalu lama.

\section{DAFTAR RUJUKAN}

Arikunto. (2013). Dasar-dasar Evaluasi Pendidikan Edisi 2. Jakarta: Bumi Aksara.

Faizi, M. (2013). Ragam Metode Mengajarkan Eksakta pada Murid. Yokyakarta: Diva Press.

Fraenkel, J. R. \&Wallen, N. E. (2007). How to Design and Evaluate Research in Education. New York: McGraw-Hill.

Marlinda, dkk. (2016). Perbandingan Penggunaan Media Virtual Lab 
Simulasi Phet (Physics Education Tekhnology) Dengan Metode Eksperimen Terhadap Motivasi Dan Aktivitas Belajar Peserta Didik Pada Materi Kelarutan Dan Hasil Kali Kelarutan. Jurnal Pendidikan Sains Indonesia, Vol.04, No.01, hlm. 79-93.

Meilinda. 2012. Upaya Peningkatan Hasil Belajar Peserta didik dengan Penerapan Metode Eksperimen pada Pembelajaran IPA di kelas $V$ SD Negeri 02 Bermani llir. Jurnal TEQIP. 1: 69-76.

Nainggolan, L. (2017). Pengembangan Media Praktikum Berbasis Laboratorium Virtual (Virtual Laboratory) pada Materi Pembelahan Sel di SMA. Jambi.

Perkins, K., W. Adams, M. Dubson, N. Finkelstein, S. Reid and C. Wieman. 2006. Phet: Interactive Simulations for Teaching and Learning Physics. The Physics Teacher, Vol.44: 18-23.

Purwanto \& Hendri. (2016). Studi Perbandingan Hasil Belajar Siswa Menggunakan Media PhET Simulations dengan Alat Peraga pada Pokok Bahasan Listrik Magnet di Kelas IX SMPN 12 Kabupaten Tebo. Jurnal Edu Fisika, 1(1), $22-27$.

Wieman, L.C. (2002). PhET Interactive Simulation.

https://phet.colorado.edu/en/. University of Colorado Boulder.

Wuryaningsih, R. (2014). Penerapan Pembelajaran Fisika dengan Media Simulasi PhET pada Pokok Bahasan Gaya untuk Meningkatkan Hasil Belajar Siswa Kelas VIIIA SMPN 6 Yogyakarta. Prosiding Pertemuan IImiah XXVIII HFI Jateng \& DIY. 400-402. 